\title{
Reproductive Strategies of Marine Benthic Invertebrates: A Settlement-Timing Hypothesis*
}

\author{
Christopher D. Todd ${ }^{1,2, * *}$ and Roger W. Doyle ${ }^{3}$ \\ 1 University of Leeds, Wellcome Marine Laboratory, Robin Hood's Bay, North Yorkshire Y022 4SL, England \\ 2 University College of North Wales, Department of Marine Biology, Marine Science Laboratories, Menai Bridge, Gwynedd, \\ LL59 5EH, North Wales \\ ${ }^{3}$ Department of Biology, Dalhousie University, Halifax, Nova Scotia B3H 4J1, Canada
}

\begin{abstract}
Evidence for nudibranch molluscs is presented which shows a clear relationship between egg-size and developmental mode (planktotrophic, lecithotrophic and direct development), egg-size and development time, and thereby larval strategy and development time. Egg-to-juvenile periods differ significantly according to strategy, with lecithotrophic pelagic development being the briefest, and planktotrophic development the longest. In addition, support of the lecithotrophic strategy necessitates a greater absolute calorific threshold on the part of the adult than does the planktotrophic strategy. It is proposed that for a given species there is an optimal time to spawn (when standing crop is at a peak) and an optimal time for the larva to settle. While accepting that in selecting for a particular strategy a compromise must be struck between such mediating factors as total and relative energy demand on the adult, egg numbers, individual probabilities of larval survival, and especially dispersal requirements, the settlement-timing hypothesis may be instrumental in resolving some paradoxical situations. Thus, for example, a species in which two or more alternative strategies appear supportable, in energetic terms, may select that strategy which appropriately 'bridges' the period between the optimal time to spawn and to settle.
\end{abstract}

\section{INTRODUCTION}

In a series of comparative studies of the life cycle and reproductive strategies of ecologically proximate species pairs (Menge, 1974, 1975; Grahame, 1977 ; Todd, 1979a) with contrasting larval types, no single deterministic feature, which predicts selection for one or other strategy, is discernible: each situation presents a 'special case' appearing explicable in specific terms. The adoption of a given larval strategy presumably results from selective pressures on a wide range of factors, including absolute and relative levels of energy available for reproduction, the advantages and disadvantages of larval dispersal, egg size and numbers, individual probabilities of larval survival, etc.

We present here evidence for nudibranch molluscs which demonstrates a clear relationship between egg size, development time and larval type; factors which are comparatively inflexible variables in the fitness equation which must be maximised. These form the

- Dedicated to Simeon A. Mileikovsky who died on Sept. 12, 1980 in Moscow

- Present address: University of St. Andrews, Gatty Marine Laboratory. St. Andrews, Fife KY 16 8LB, Scotland integral part of the settlement-timing hypothesis which purports not to explain why every benthic marine invertebrate species has adopted a particular strategy, rather how development time may be the balancing or determining factor in instances where two or more strategies appear optional in energetic terms.

The analytical models outlines by Vance $(1973 \mathrm{a}, \mathrm{b})$ have been subject to much subsequent argument (e.g. Underwood, 1974; Vance, 1974; Steele, 1977; Strathmann, 1977; Turner and Lawrence, 1979; Todd, 1979a). One of their greatest inadequacies lies in not accounting for the different egg-to-juvenile periods represented by the basic planktotrophic, lecithotrophic and direct (non-pelagic) strategies. The present paper presents an intuitive model which is based upon the concept that in conditions of seasonally varying resources there is an optimal time for a given invertebrate species to reproduce, and an optimal time for the larva to settle. In cases where two or more larval strategies appear to be energetically supportable by that species (e.g. Todd, 1979a) selection ought to favour that strategy which closes the differential timegap appropriately. 
Supportive data are presented from studies of North Atlantic nudibranchs, a group which encompasses a wide range of ecological associations and larval types and strategies. Specifically, observations on the bryozoan-grazing dorid nudibranchs Onchidoris muricata (Muiller) and Adalaria proxima (Alder and Hancock), and the barnacle predator Onchidoris bilamellata (L.) are discussed. Annual species, such as these, with no overlap of generations and a single, discrete, breeding season are felt best suited to testing this hypothesis: such semelparous invertebrates are likely to display highly adapted modes of reproduction since total reproductive failure throughout the species' geographical range cannot be tolerated within any one year.

Onchidoris muricata and Adalaria proxima are largely intertidal and prey upon a wide range of Bryozoa, but especially Electra pilosa (L.). Juveniles are first detectable in the field in June and reproduction commences in February, terminating in May and peaking in mid-March (Todd, 1979a). O. muricata reproduces by means of small ( $90 \mu \mathrm{m})$ eggs which hatch as poorly-developed planktotrophic veligers. The extent of the pelagic phase is unknown, but is estimated to be of some $60 \mathrm{~d}$ duration at ambient temperatures (Todd, 1979a). A. proxima, by contrast, reproduces with larger $(180 \mu \mathrm{m})$ eggs hatching as well-developed lecithotrophic veligers which are pelagic for only $24-48 \mathrm{~h}$ prior to settling on live Electra (Thompson, 1958).

Onchidoris bilamellata preys upon a number of symmetrical barnacle species but in view of its largely intertidal distribution is primarily associated with Balanus balanoides (L.). Spawning commences in late December/early January, peaking in mid-January and terminating in April. The small $(100 \mu \mathrm{m})$ eggs hatch as planktotrophic larvae which require an extended period of pelagic feeding to complete development and metamorphosis. Laboratory-cultured veligers metamorphosed only in the presence of live barnacles (Todd, 1979b, c) and no intermediate diet was inferred. In view of the small size of $O$. bilamellata at metamorphosis $(0.5 \mathrm{~mm})$ it is apparent that only postmetamorph barnacles are sufficiently small to be eaten (Todd, 1979b). We suggest, therefore, that the predator must time its reproduction so that settlement of postmetamorph dorids is coincident with spat fall of $B$. balanoides in April/May. The reproductive strategy of $O$. bilamellata thus must be timed to meet a specific settlement deadline in order to key into the seasonal availability of its exclusive food resource, and it is this that the settlement-timing hypothesis attempts to resolve. In this context it is important to note that the prosobranch dogwhelk Nucella lapillus (L.) - a potential competitor - reproduces by means of a lecithotrophic, non-pelagic, strategy.

\section{MATERIALS AND METHODS}

All analytical methods have been outlined in previously published accounts (Todd, 1979a, b). Briefly, calorific determinations were obtained from freezedried materials combusted in a Phillipson Oxygen micro-bomb calorimeter: all values quoted are mineral ash-free. Embryonic development-time observations for Onchidoris bilamellata were made on laboratoryspawned egg-masses maintained in incubators at $4^{\circ}-5^{\circ} \mathrm{C}(\mathrm{n}=17), 7^{\circ} \mathrm{C}(\mathrm{n}=10), 10^{\circ} \mathrm{C}(\mathrm{n}=6), 16^{\circ} \mathrm{C}$

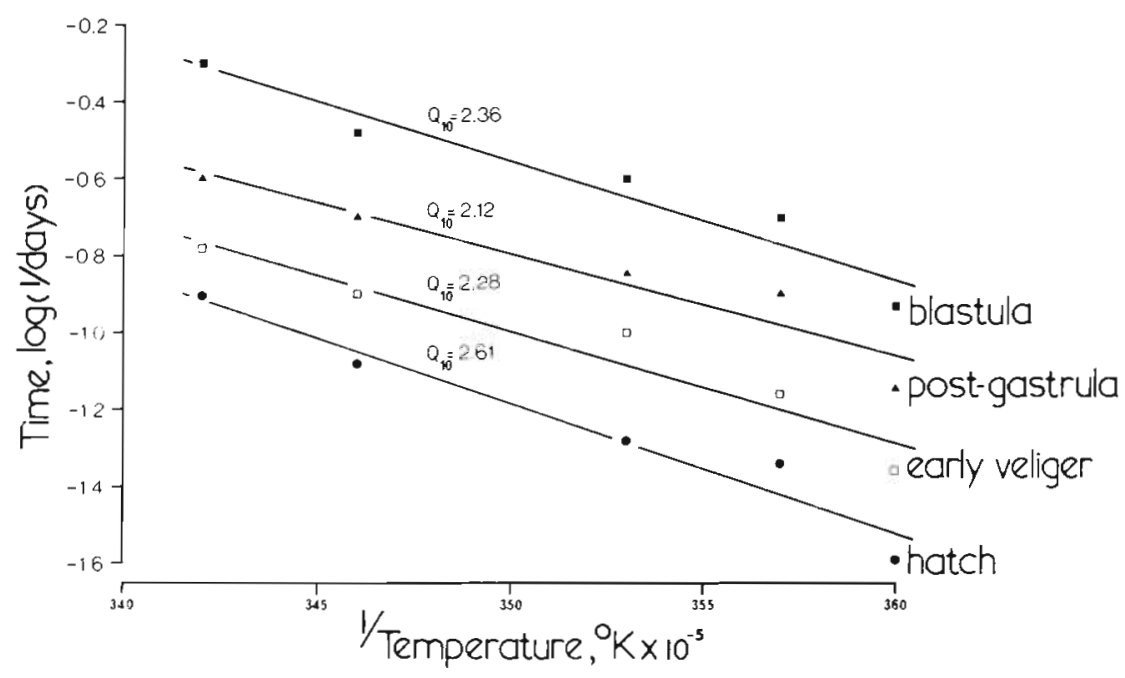

Fig. 1 Onchidoris bllamellata. Arrhenius plots for development times to 4 selected embryonic stages. The mean slope of 2.34 was used as $Q_{10}$ for subsequent analyses 
$(\mathrm{n}=1)$ and $19^{\circ} \mathrm{C} \quad(\mathrm{n}=3)$. All egg-masses were observed daily, and a total of 16 recognisable stages (from 1st cleavage through to hatching) noted. Arrhenius plots from least squares regression analyses are presented for these 4 stages in Figure 1. From the mean value for these 4 data-sets a $Q_{10}$ of 2.34 was derived for application to published data for a range of nudibranch species. For comparative purposes the various development-time data have been standardised to $10^{\circ} \mathrm{C}$ using this $Q_{10}$ value. In order to estimate the development time at $10^{\circ} \mathrm{C}$ from another temperature the relationship

$$
\text { Rate }_{\left(t=t_{0}\right)}=\text { Rate }_{\left(t-\omega_{0}\right)} \cdot 10^{0.034\left(t_{x}-t_{0}\right)}
$$

where $t_{x}=10^{\circ} \mathrm{C}$, is utilised.

\section{RESULTS}

\section{Egg Size and Development Time}

Figure 1 presents the development-time data for embryogenesis of Onchidoris bilamellata over a range of temperatures from $4^{\circ}-5^{\circ} \mathrm{C}$ to $19^{\circ} \mathrm{C}$. Least squares regression analyses of the semi-log reciprocal plots show a distinct relationship between temperature and development time although development at the lowest temperature was disproportionately slow The four regression coefficients ranged from 2.12 to 2.61 , and hence the mean value of 2.34 has been selected for subsequent analyses.

Development times, at various temperatures, for 30 species of nudibranchs have been collated from the literature (Table 1) and 'corrected' to a standard $10^{\circ} \mathrm{C}$ utilising the $Q_{10}$ of 2.34 (Fig. 2). Only North Atlantic (mostly European) species, and only those for which reliable measurements of egg diameter and regulation of experimental temperature were reported, have been utilised. Typically, for boreal nudibranchs, the majority of species (20) have long-term pelagic planktotrophic larvae while fewer (7) have short-term pelagic lecithotrophic larvae, and yet fewer still (3) have totally benthic development with vestigial, intracapsular, larval stages. Note that Tenellia pallida (A. \& H.), which may undergo metamorphosis of the lecitho-

Table 1. Numeration of nudibranch species and sources of data for data points in Figure 2. References marked with an asterisk are reviewed in Thompson (1967); others are cited in the reference list below. P: long-term pelagic planktotrophic larvae; L: short-term pelagic lecitrophic larvae; D: totally benthic development

\begin{tabular}{|c|c|c|c|}
\hline Species & Larval type & Remarks & Authority \\
\hline 1. Eubranchus exiguus (A. \& H.) & $\mathrm{P}$ & & Kress, 1972 \\
\hline 2. Coryphella lineata (Lovén) & $\mathrm{P}$ & & Miller, $1958^{\circ}$ \\
\hline 3. Acanthodoris pilosa (Müller) & $\mathrm{P}$ & & Miller, $1958^{\bullet}$ \\
\hline 4. Tritonia plebeia Johnston & $\mathrm{P}$ & & Thompson, 1967: pers. \\
\hline 5. Tergipes tergipes (Forskal) & $\mathrm{P}$ & ( = T.despectus) & Tardy, $1964^{\circ}$ \\
\hline 6. Facelina coronata (Müller) & $\mathrm{P}$ & $(=$ F.auriculata $)$ & Thompson, 1967 \\
\hline 7. Doto coronata (Gmelin) & $\mathrm{P}$ & & Schmekel \& Kress, 1977 \\
\hline 8. Eubranchus cingulatus (A. \& H.) & $\mathrm{P}$ & & Kress, 1972 \\
\hline 9. Tenellia pallida (A. \& H.) & $\mathrm{P} / \mathrm{L}$ & See text & Eyster, 1979 \\
\hline 10. Onchidoris muricata (Müller) & $\mathrm{P}$ & & Miller, $1958^{\circ}$ \\
\hline 11. Eubranchus pallidus (A. \& H.) & $P$ & & Kress, 1972 \\
\hline 12. Catriona aurantia (A. \& H.) & $\mathrm{P}$ & & Kress, 1972 \\
\hline 13. Eubranchus farrani (A. \& H.) & L & & Personal; Kress, 1972 \\
\hline 14. Doto coronata agg. (Gmelin) & P & Species uncertain & Thompson, 1967 \\
\hline 15. Polycera quadrilineta (Müller) & $P$ & & Thompson, 1967 \\
\hline 16. Doto pinnatifida (Montagu) & $\mathrm{P}$ & & Schmekel \& Kress, 1977 \\
\hline 17. Hero formosa (Lovén) & $\mathrm{P}$ & & Thompson, 1967 \\
\hline 18. Onchidoris bilamellata (L.) & $\mathrm{P}$ & This paper & Personal \\
\hline 19. Doto fragilis (Forbes) & $\mathrm{P}$ & & Schmekel \& Kress, 1977 \\
\hline 20 Precuthona peachii (A. \& H.) & $\mathrm{L} / ? \mathrm{P}$ & See text & Christensen, 1977 \\
\hline 21. Jorunna tomentosa (Cuv.) & $\mathrm{P}$ & Biennial lifecycle & Miller, $1958^{\circ}$ \\
\hline 22. Eubranchus doriae (Trinchese) & L & & Tardy, 1962 \\
\hline 23. Archidoris pseudoargus (Rapp) & $P$ & $\begin{array}{l}\text { Biennial lifecycle (eggsize } \\
\text { requires confirmation) }\end{array}$ & Miller, $1958^{\circ}$ \\
\hline 24. Cuthona nana (A. \& H.) & $\mathrm{L} / ? \mathrm{P}$ & See text & Harris et al., 1975 \\
\hline 25. Dendronotus frondosus Ascanius & L & & Miller, $1958^{\circ}$ \\
\hline 26. Tritonia hombergi Cuv. & L & Biennial lifecycle & Thompson, $1962^{\circ}$ \\
\hline 27. Adalaria proxima (A. \& H.) & L & & Thompson, 1958 \\
\hline 28. Coryphella stimpsoni (Verrill) & $\mathrm{D}$ & & Morse, 1971 \\
\hline 29. Aeolidiella alderi (ocks) & $\mathrm{D}$ & $(=$ Eolidina alderi $)$ & Tardy, $\mathbf{1 9 6 2}^{\circ}$ \\
\hline 30. Cadlina laevis (L.) & $\mathrm{D}$ & & Thompson, 1967 \\
\hline
\end{tabular}


trophic veliger within the egg-capsule (Eyster, 1979) has been included in the lecithotrophic category. The data pertaining to Precuthona peachii (A. \& H.) and Cuthona nana (A. \& H.) are somewhat enigmatic in that these species may be synonymous and, furthermore, switching of egg size and larval strategy (as in Tenellia) may occur. Although the veliger of Archidoris pseudoargus (Rapp) is undoubtedly planktotrophic the reported egg size has resulted in a possible misclassification in Figure 2: these measurements clearly require confirmation.

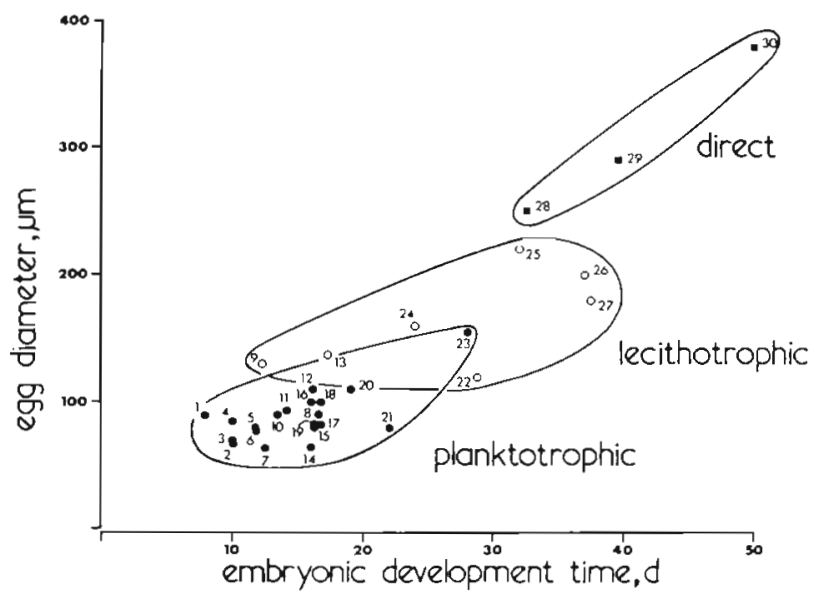

Fig. 2. Capsular development time for a range of North Atlantic nudibranch species, 'corrected' to $10^{\circ} \mathrm{C}$ (see text). For species identities and authorities consult Table. 1. The 'lecithotrophic' forms hatch as briefly swimming veligers while the 'direct' forms hatch as benthic juveniles

Three significant factors are apparent from the data presented in Figure 2. Firstly, there is a distinct, approximately linear, relationship between egg size and larval (or developmental) type, and thereby between larval type and development time. That a causal relationship exists between egg size and larval type amongst marine invertebrates is a well established principle (e.g. Thorson, 1946, 1950; Ockelmann, 1965; see also Hermans, 1979 and Turner and Lawrence, 1979, for recent reviews) while a relationship between egg size and development time has been the subject of much recent argument (see 'Discussion'). Note that the data in Figure 2 include only the intra-capsular development periods: consideration of the additional pelagic phase of planktotrophic and lecithotrophic larvae is given below.

\section{Optimal Spawning Time}

Fecundity is generally a function of individual body size, and thence of standing crop for populations. It is
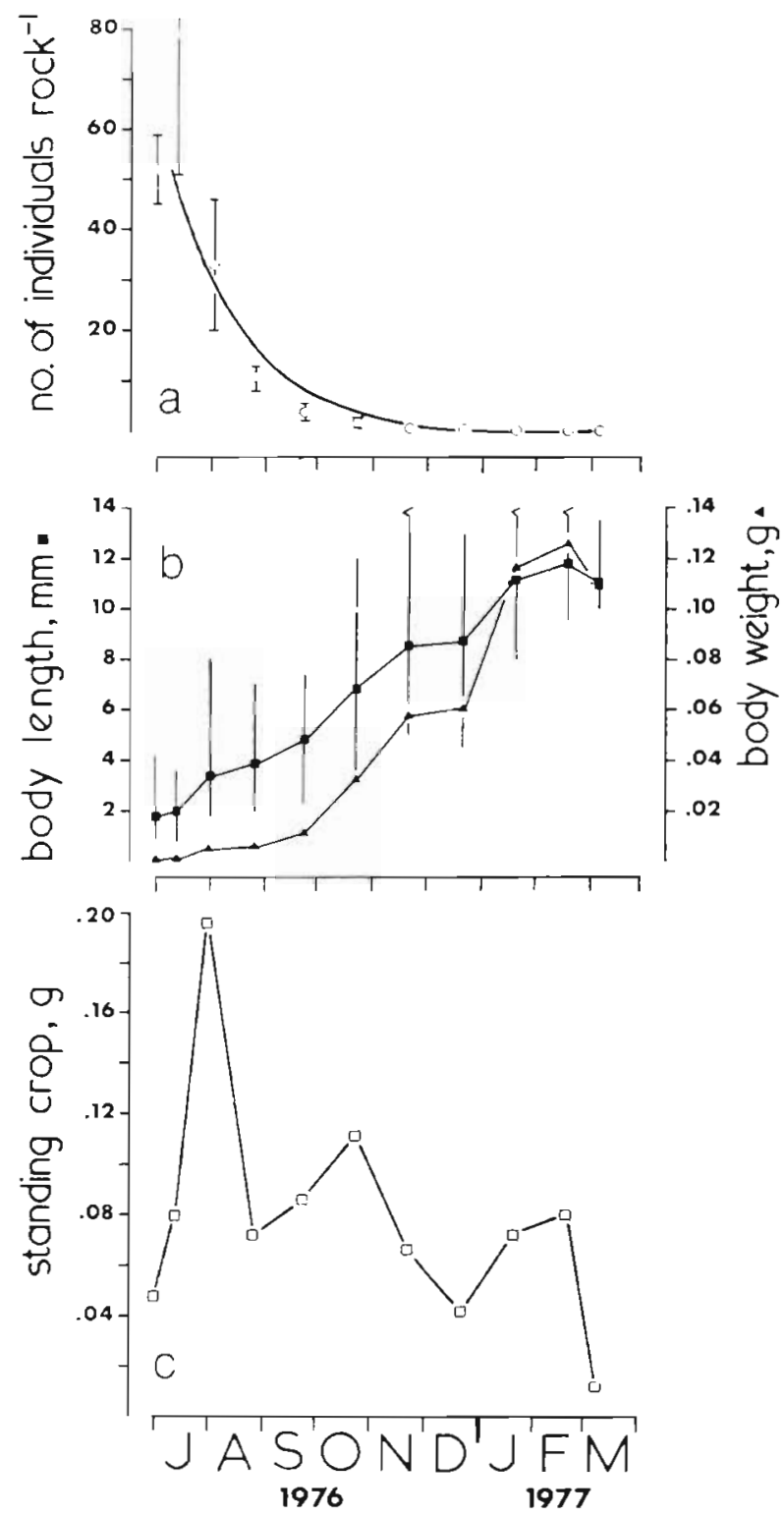

Fig. 3. Onchidoris bilamellata. Population data for the 1976 , 77 generation at Cowling Scar, Robin Hood's Bay, North Yorkshire, UK. Bars (b) indicate ranges of body lengths. Data from Todd (1979b)

to be anticipated, therefore, that overall fitness be maximised by reproduction coinciding with peak biomass at a time near to that at which reproduction is necessary. The interaction between individual growth and population mortality-rates may result in a standing crop remaining constant with time, or 'peaking' at one or more time(s). The most complete data for a nudibranch species concern Onchidoris bilamellata (Todd, $1979 b, c)$ : Figure 3 summarises the growth and mortality of an intertidal population at Robin Hood's Bay, North Yorkshire in 1976/77. Mortality followed a density-dependent exponential function (Fig. 3a) with 
the number of individuals surviving to reproduce from January to April 1977 being a small fraction (<1\%) of those initially recruited. Body size increased linearly throughout the season (Fig. 3b), peaking in January/ February. Conversion of individual body lengths to damp weight from a power curve regression

$\left(\log _{c} y=\log _{e} 0.00013+\left(2.797 . \log _{e} x\right), \quad r=0.990 ; n=\right.$ $88 ; \mathrm{p}<0.001$.) showed mean body weight to increase with a corresponding curve function (Fig. 3b), and monthly standing crop to display 3 peaks (Fig. 3c). The maximum biomass, recorded in July/August, was considerably greater than the two subsequent peaks owing to the initially high density of juveniles. It can be seen, however, that mortality is such that standing crop would never subsequently exceed the January/ February peak and that this is the optimal time for spawning. Spawning was well under way by January 19,1977 , but had not yet commenced on December 21 . 1976

The task to be resolved by the nudibranch, as a specialist predator of Balanus balanoides, is to synchronise the settlement of its larvae to settlement of its prey barnacle since adult barnacles are too large to be attacked by post-metamorph $O$. bilamellata (pers. obs.). Juveniles encountering $B$. balanoides before the spring spatfall in April/May will starve, as will those settling too long after $B$. balanoides, which will have grown into a size refuge. For $O$. bilamellata, therefore, there is both an optimal time to spawn and to settle, between which lies a period of some 13 weeks - a gap which must be bridged by either a pelagic larval, or totally benthic, reproductive strategy. Moreover, the settlement target time is not fixed: $B$. balanoides peak settlement is subject to annual and geographical variation of up to several weeks (see 'Discussion').

\section{Egg-to-Juvenile Periods in Relation to Larval Strategy}

Successful larval culture of the long-term planktotrophic veliger of Onchidoris bilamellata (in prep.) was achieved at Menai Bridge, UK. The larva hatches as a typical, poorly-developed veliger with a small foot, no propodium and no eyes. Larvae were reared at $15^{\circ} \mathrm{C}$ in UV-sterilised, $0.2 \mu \mathrm{m}$ filtered seawater in $200 \mathrm{l}$ bins and fed a mixture of flagellates (Tetraselmis sp., Rhodomonas balthica and Pavlova lutheri [Droop]) at a total concentration of 100 cells $\mu \mathrm{l}^{-1}$. No antibiotics were necessary. The competent pediveliger, with eyes and a large propodium, was attained after $32 \mathrm{~d}$ and the stimulus to metamorphose has been shown to be the presence of live barnacles (adult Chthamalus stellatus [Poli], Elminius modestus Darwin and Balanus balanoides were used). Correction of the duration of the pelagic larval phase to ambient field temperature $\left(\bar{x}=6{ }^{\circ} \mathrm{C}\right)$, using the $Q_{10} 2.34$, indicates an actual pelagic life of $69 \mathrm{~d}$. This, added to the observed embryonic development time of $39 \mathrm{~d}$ at field temperatures, gives an egg-to-juvenile period of $108 \mathrm{~d}$. Laboratory and field observations of spawning of $O$. bilamellata (Todd, 1979b, c) have shown that peak spawn production occurs in mid-January. Thus, the planktotrophic strategy adopted will result in peak settlement amongst Balanus in early May (Fig. 4), the time at which $B$, balanoides cyprids are settling in the intertidal.

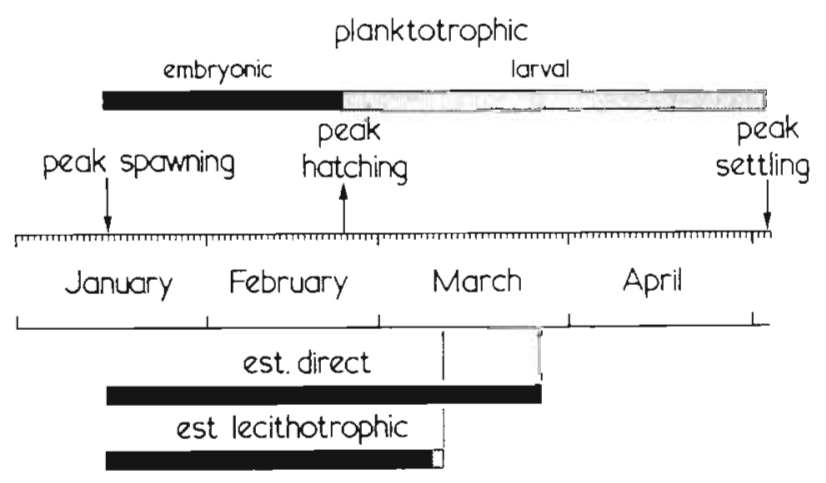

Fig. 4. Onchidoris bilamellata. Upper half: planktotrophic strategy and peak settling in late April/early May. Lower half: projected peak settlement times if the direct $(400 \mu \mathrm{m}$ eggs) and lecithotrophic pelagic (180 $\mu \mathrm{m}$ eggs) strategies were adopted

The question as to whether or not the lecithotrophic pelagic, or direct (non-pelagic) strategies might suffice for Onchidoris bilamellata is best considered in relation to the development of two closely related intertidal dorid species, Adalaria proxima and Cadlina laevis, all three being sympatric. As has been previously noted (Todd, 1979a) in considering the larval strategies of Adalaria proxima and $O$. muricata, the lecithotrophic strategy appears to confer the shortest egg-to-juvenile period ( $A_{2} B$; Fig. 5). A. proxima eggs $(180 \mu \mathrm{m})$ require approximately $49 \mathrm{~d}$ to hatch at $7^{\circ} \mathrm{C}$ and the lecithotrophic veliger may be pelagic for only 24-48 h before settling (Thompson, 1958). Conversely, Cadlina eggs $(400 \mu \mathrm{m})$ - which undergo vestigial larval stages within the capsule - require approximately $50 \mathrm{~d}$ at $10^{\circ} \mathrm{C}$ to complete their development and hatch as juveniles (Thompson, 1967). Application of the $Q_{10}$ 2.34 predicts the total embryonic phase of Cadlina in the field $\left(\vec{x}=6^{\circ} \mathrm{C}\right)$ to be of some $71 \mathrm{~d}$ duration, while that for Adalaria $\left(\bar{x}=6{ }^{\circ} \mathrm{C}\right)$ to be $55 \mathrm{~d}$. Thus, if $O$. bilamellata were to adopt the lecithotrophic strategy with $180 \mu \mathrm{m}$ eggs, and peak spawning in mid-January (January 15), peak settlement would occur around March 11 (Fig. 4). Similarly, if the non-pelagic strategy with $400 \mu \mathrm{m}$ eggs (such as Cadlina produces) were adopted, peak hatching (= settlement) would occur around March 27. Both of these dates are considerably 


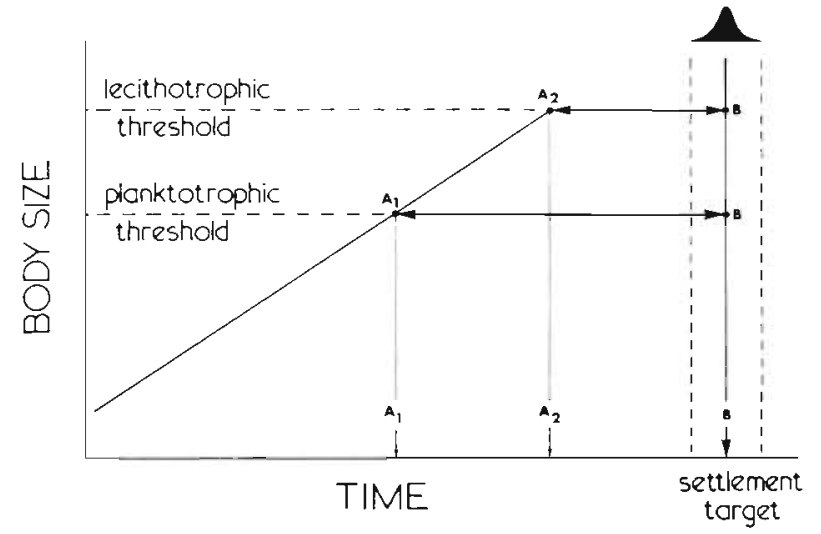

Fig. 5. Schematic representation of settlement-timing hypothesis. Two hypothetical species share the same settlement target but the larger species has a later optimal time to spawn. Due to the brevity of the time gap $\left(A_{2} B\right)$ the larger species adopts a lecithotrophic strategy in spite of the fact that it could also support the planktotrophic strategy. The smaller species is forced into planktotrophy $\left(A_{1} B\right)$ for both temporal and energetic reasons

earlier than the target of May 3, when Balanus balanoides is settling. Thus, for nudibranchs at least, the 3 fundamental developmental types incur egg-tojuvenile periods sufficiently different that they are not interconvertible in analytical models (e.g. Vance, $1973 a$, b). The lecithotrophic strategy offers the briefest egg-to-juvenile period ( $A_{2} B$; Fig. 5), while planktotrophy is the longest $\left(A_{1} B_{;}\right.$Fig. 5), and direct development intermediate. Thus, while accepting the importance of other factors - such as larval dispersal capabilities or requirements, total energetic demand on the adult, individual probabilities of larval survival and numbers of eggs producible - it may be that a particular strategy is adopted in a specific instance in order to provide best timing of settlement after spawning.

\section{Larval Strategy and Reproductive Effort}

Menge $(1974,1975)$ concluded that brooding of large lecithotrophic eggs and non-pelagic development by the intertidal asteroid Leptasterias hexactis is a coadaptive consequence of competition-induced small size. The much larger Pisaster ochraceus disperses large numbers of small pelagic eggs which develop as long-term planktotrophic larvae and which are proposed to serve in colonising disjunct habitats of higher quality prey. Grahame (1977), on the other hand, invoked $r$ - $K$ selection theory to explain the relatively high energy demand, planktotrophic strategy of the small intertidal prosobranch Lacuna vincta as opposed to the relatively lower energy demand, direct (lecithotrophic) strategy of the slightly larger Lacuna pallidula. Similarly, energy considerations, and differ- ences in relative energy demand were implied by Todd (1979a) in rationalising the planktotrophic strategy of the intertidal nudibranch Onchidoris muricata against the lecithotrophic strategy of its slightly larger, potential competitor Adalaria proxima. For these two pairs of species the lecithotrophic strategy necessitates a higher absolute energy threshold (Fig. 5). For example, Adalaria was concluded to have opted for lecithotrophy, with its higher probabilities of individual larval survival, rather than planktotrophy, thus offsetting or dampening the unpredictability of energy available to individual adults for reproduction. The smaller $O$. muricata, however, is apparently forced into planktotrophy since this species cannot attain the absolute calorific threshold necessary to support the lecithotrophic strategy - in spite of outputting up to the equivalent of its own body calories in spawn and making the higher relative 'effort'.

Returning to Onchidoris bilamellata, it is apparent from the above observation on $O$. muricata $(24-54 \mathrm{cal}$ pair $^{-1}$; Todd, 1979a) and A. proxima (50-100 cal pair $^{-1}$; Todd, 1979a) that in absolute calorific terms the lecithotrophic strategy would be clearly supportable by $O$. bilamellata $\left(1715-2699 \mathrm{cal} \mathrm{pair}^{-1}\right)$. Although energetic data are lacking for reproduction in Cadlina laevis (non-pelagic), it is certain that $O$. bilamellata will exceed the absolute and relative calorific output of this species by at least an order of magnitude (pers. observ.). The paradox of $O$. bilamellata selecting for planktotrophy rather than non-pelagic development, as shown by Nucella lapillus, or pelagic lecithotrophy, does not simply relate to energetic considerations: we propose that the differential egg-to-juvenile time periods conferred by the differing developmental modes are of primary importance here (Figs 4 and 5). Thus, adults of those species that can attain only the planktotrophic threshold have no option; persistence of these species depends upon whether or not the eggto-juvenile period can be fitted to the time gap conferred by the optimal time to spawn and the settlement target. Conversely, those species which can attain the (higher) lecithotrophic and/or direct (non-pelagic) thresholds have the potential to reproduce in one of 2 or 3 ways, selection going to that strategy which best bridges the gap.

\section{DISCUSSION}

With the inclusion of the above data for nudibranch molluscs there is now an overwhelming body of data (for review see Steele, 1977; Strathmann, 1977) which shows a clear relationship between egg size and development time amongst marine invertebrates. In 
this respect, Underwood's (1974) major criticism of Vance's (1973a, b) models of reproductive strategies is quite unjustified. Underwood presented regression analyses of developmental period on egg size for a range of prosobranch species, reported by Thorson (1946), which showed no significant correlation: an unsurprising result since the data were not standardised to uniform temperature. Undoubtedly, the present analyses (Fig. 2) will include a small intrinsic error, in that standardisation for a range of egg sizes and larval types has been effected using a single $Q_{10}$ determination of the effect of temperature on development time for a planktotrophic species. Indeed, Vernberg and Costlow (1966) showed changes in the $\mathrm{Q}_{10}$ of oxygen consumption of two larval, and the postlarval, stages of several species of the decapod genus Uca. Furthermore, they observed different respiratory responses of megalopa larvae of two temperate $U c a$ spp. from a range of latitudinal regions. Since, however, in the present case we are concerned with the gross temporal differences in egg-to-juvenile periods conferred by the three reproductive strategies, such error is not considered to be important. From these observations of a direct relationship between egg size and developmental period, and between egg size and larval type, it follows that the observed differential egg-to-juvenile periods are to be anticipated. The ecological significance of especially this latter feature is further emphasised by the fact that in most species egg size within and between individuals is comparatively invariate: that is, genetic fixation of egg size has consequently rigid implications on the time required to attain the juvenile status.

Environmental temperature is an important element of this hypothesis for two major reasons. Firstly, a species opting to spawn at a given time of year will be confronted by a more or less specific range of temperature with concomitant effects on development time. From the above analyses it is apparent that the simplest manner in which the species might adjust the egg-to-juvenile period is by altering egg size (which is genetically fixed) and thereby larval strategy. Indeed, a few instances of switching of egg size and larval strategy have been observed for a wide range of invertebrates, especially polychaetes (e. g. Rasmussen, 1973; Curtis, 1977) and opisthobranchs (Harris et al., -1975; Clark and Goetzfried, 1978; Rivest, 1978; Clark et al., 1979; Eyster, 1979). In the present context, however, of greater relevance are the observations of strategy switching in some molluscs not by means of altering egg size but in the variable provision of extrazygotic yolk. Thorson (1946) found that the prosobranch Natica catena (da Costa) varies between nonpelagic and pelagic (planktotrophic) development due to respectively high and low numbers of 'nurse-eggs' associated with the encapsulated embryo. Similarly, Clark et al. (1979) showed that developing embryos of the sacoglossan opisthobranch Elysia cauze Marcus are provided with additional nutrition from a granular yolk-ribbon ramifying the egg mass. Development varied seasonally between planktotrophy (spring), lecithotrophy (summer), and direct development (autumn) according to variable utilisation of the yolk ribbon. Evidently, these are instances of the species attempting to abbreviate the otherwise prolonged capsular developmental period by means of extrazygotic yolk rather than producing larger, more slowly cleaving (Jägersten, 1972) yolky eggs.

Secondly, environmental temperature has an important seasonal effect on development rates of boreal or temperate invertebrates. Most species reproduce in spring (Thorson, 1946) when ambient temperature is rising, albeit slowly. The later produced eggs and larvae will therefore experience somewhat higher temperatures and correspondingly decreased developmental time. The net result will be a 'telescoping' of the reproductive phase from a more or less extended period of egg laying such that larvae competent to settle occur together. Conversely, species spawning in autumn/early winter would be subject to decreasing temperatures and a corresponding temporal dispersion of settling larvae, which within a few generations could lead to a total breakdown of synchrony of individuals within a population.

That a given species has an optimal settlement target date might be open to various interpretations. Certainly, in the case of Onchidoris bilamellata described here, this appears to be a valid concept. Peak settlement of the major prey organism, Balanus balanoides, does not, however, occur at a fixed date even for a particular locality. Liberation of nauplii by B. balanoides often occurs in several peaks and the timing is unpredictable within a few weeks (Barnes and Barnes, 1954; J. R. Lewis, pers. comm.). Settlement of cyprids often occurs similarly in several 'waves', separated by up to $14 \mathrm{~d}$, over the period April-June though the major spatfall occurs in late April/early May. Within the U.K. there is an approximate cline of earlier naupliar release and cyprid settlement from the southwest to the northeast. Even within this generalisation, however, the timing of cyprid settlement is not invariable at any fixed locality (J. R. Lewis, pers. comm.) and in this respect comparative data for populations of $O$. bilamellata in Cornwall would be most valuable. At the northern limits, $B$. balanoides spatfall occurs as late as July-August in Spitzbergen (Barnes, 1957). Significantly, the southern limits of distribution of $O$. bilamellata and $B$. balanoides are coincident on the French Atlantic coast (Bouchet and Tardy, 1976). Thus, the settlement target of $O$. bilamellata, although 
precise in nature, is somewhat unpredictable in time. For this reason the ability for the pediveliger of $O$. bilamellata to delay metamorphosis might be of paramount importance.

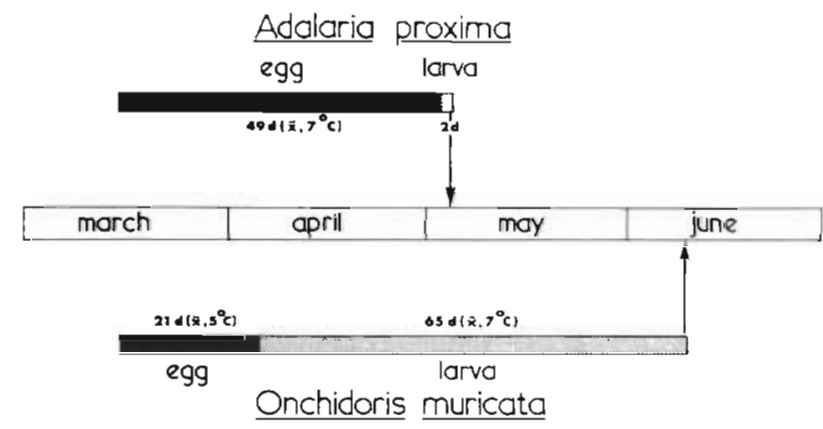

Fig. 6. Adalaria proxima (lecithotrophic, pelagic) and Onchidoris muricata (planktotrophic). Data from Todd (1979a) showing the differing optimal times to settle for these two species, which preferentially graze the same prey Bryozoan Electra pilosa. In these cases, the species share the same optimal time to spawn in mid-March

Whereas Onchidoris bilamellata is subject to prey size constraints at the initial juvenile stages, the bryozoan predators $O$. muricata and Adalaria proxima have no such problems: the colonies of Electra are perennial and the prey is present in the form of multiple individuals (polypides) of unit size, sufficiently small for even juveniles to handle. If one were to invoke the settlement-timing hypothesis to account for the disparate larval strategies of these two species (Figs 5 and $6)$, what might the settlement target be? The answer may lie in the larger body size of $A$. proxima. Since peak spawn output for both species is coincident in mid-March (Fig. 6 and Todd, 1979a), A. proxima settles some 4 weeks prior to $O$. muricata resulting in benthic juvenile-adult phases of 10.5 and 9.5 months respectively. Since $A$. proxima has a larger body size than $O$. muricata (utilising the same prey resource) the earlier settlement target date may simply relate to $A$. proxima having to reoccupy the benthic habitat as quickly as possible in order to maximise adult growth. Certainly, in energetic terms, the planktotrophic strategy would be easily supportable by A proxima (Todd, 1979a). A similar settlement target might be invoked for herbivores of perennial algae, the grazers having to settle by a specific date in order to attain a body size sufficient to permit successful over-wintering.

It should be further emphasised that the total developmental period is only one of many factors important in reproduction and that a compromise must be struck between the optimal larval type predicted by the settlement-timing hypothesis and additional features, notably larval dispersal. In this respect one is confronted with a cause-effect syndrome whereby a highly adapted overall reproductive strategy is to be expected for extant species. The hypothesis does, however, provide a basis for helping to explain the adoption of pelagic lecithotrophy rather than planktotrophy by Adalaria proxima, and planktotrophy rather than non-pelagic development by Onchidoris bilamellata.

Acknowledgements. One of us (C. D. T.) would like to express his appreciation to Dr. J. R. Lewis for supervising part of this work during tenure of a Natural Environment Research Council Studentship. For thoughtful discussion, thanks are due to Drs G. R. F. Hicks and D. A. Jones. R. W. D. was supported by a NATO Research Fellowship.

\section{LITERATURE CITED}

Barnes, H. (1953). The effect of light on the growth rate of two barnacles, Balanus balanoides (L.) and B. crenatus (Brug.) under conditions of total submergence. Oikos 4: 104-111

Barnes, H. (1957). The northern limits of Balanus balanoides. Oikos 8: 1-15

Barnes, H., Barnes, M. (1954). The general biology of Balanus balanus (L.). Oikos 5: 63-76

Bouchet, P., Tardy, J. (1976). Faunistique et biogéographie des nudibranches des côtes Françaises de l'Atlantique et de la Manche. Ann. de l'Inst. Oceanogr. 52; 205-213

Christensen, H. (1977). Feeding and reproduction in Precuthona peachii (Mollusca Nudibranchia). Ophelia 16: 131-142

Clark, K. B., Goetzfried, A. (1978). Zoogeographic influences on development patterns of North Atlantic Ascoglossa and Nudibranchia, with a discussion of factors affecting egg size and number. J. mollusc. Stud. 44: 283-294

Clark, K. B., Busacca, M. B., Stirts, H. (1979). Nutritional aspects of development of the Ascoglossan, Elysia cauze. In: Stancyk, S. E. (ed.) Reproductive ecology of marine invertebrates. University of South Carolina Press, Columbia, S.C. (Belle W. Baruch Library in Marine Science, No. 9: 11-24)

Curtis, M. A. (1977). Life-cycles and population dynamics of marine benthic polychaetes from the Diskö Bay area of West Greenland. Ophelia 16: 9-58

Eyster, L. S. (1979). Reproduction and developmental variability in the opisthobranch Tenellia pallida. Mar. Biol. 51: $133-140$

Grahame, J. (1977). Reproductive effort and $r$ - and K-selection in two species of Lacuna (Gastropoda: Prosobranchia). Mar. Biol. 40: 217-224

Harris, L. G., Wright, L. W., Rivest, B. R. (1975). Observations on the occurrence and biology of the Aeolid nudibranch Cuthona nana in New England waters. Veliger 17: $264-268$

Hermans, C. O. (1979). Polychaete egg sizes, life histories and phylogeny. In: Stancyk (ed.) Reproductive ecology of marine invertebrates. University of South Carolina Press, Columbia, S.C. (Belle W. Baruch Library in Marine Science, No. 9: 1-9)

Jägersten, G. (1972). Evolution of the metazoan life cycle: a comprehensive theory, Academic Press, New York

Kress, A. (1972). Veränderungen der Eikapselvolumina während der Entwicklung verschiedener Opisthobranchier-Arten (Mollusca, Gastropoda). Mar. Biol. 16: 236-252

Menge, B. A. (1974). Effect of wave action and competition on 
brooding and reproductive effort in the seastar Leptasterias hexactis. Ecology 55: 84-93

Menge, B. A. (1975). Brood or broadcast? The adaptive significance of different reproductive strategies in the two intertidal seastars Leptasterias hexactis and Pisaster ochraceus. Mar Biol. 31.87-100

Morse, M. P. (1971). Biology and life history of the nudibranch mollusc, Coryphella stimpsoni (Verrill). Biol. Bull. mar biol. Lab., Woods Hole 140: 84-94

Ockelmann, K. W. (1965). Developmental types in marine bivalves and their distribution along the Atlantic coast of Europe. Proc. Europ. Malacol. Congr 1: 23-35

Rasmussen, E. (1973). Systematics and ecology of the Isjefjord marine fauna (Denmark). With a survey of the eelgrass (Zostera) vegetation and its communities. Ophelia 11: $1-495$

Rivest, B. R. (1978). Development of the eolid nudibranch Cuthona nana (A. \& H.), and its relationship with a hydroid and hermit crab. Biol. Bull. mar. biol. Lab., Woods Hole 154: 157-175

Schmekel, L., Kress, A. (1977). Die Gattung Doto (Gastropoda: Nudibranchia) im Mittelmeer und Armelkanal, mit Beschreibung von Doto acuta, n. sp. Malacologia 16: $467-499$

Steele, D. H. (1977). Correlation between egg size and developmental period. Am. Nat. 111: 371-372

Strathmann, R. R. (1977). Egg size, larval development, and juvenile size in benthic marine invertebrates. Am. Nat. 111: $373-376$

Tardy, J. (1962). Observations et expériences sur la métamorphose et la croissance de Capellinia exigua (A. et H.) (Mollusque Nudibranche). C. R. Acad. Sci. Fr. 258: $1635-1637$

Thompson, T E. (1958). The natural history, embryology, larval biology and post larval development of Adalaria proxima (A. and H.) (Gastropoda: Opisthobranchia). Phil. Trans. R. Soc. (Ser. B) 242: 1-58

Thompson, T. E. (1967). Direct development in a nudibranch,
Cadlina laevis, with a discussion of developmental processes in Opisthobranchia. J. mar biol. Ass. U.K. 47: 1-22

Thorson, G. (1946). Reproduction and larval development of Danish marine bottom invertebrates, with special reference to the planktonic larvae in the Sound (Øresund). Meddr Kommn. Danm. Fisk.og Havunders. (Ser Plankton) $4: 1-523$

Thorson, G. (1950). Reproductive and larval ecology of marine bottom invertebrates. Biol. Rev. 25: 1-45

Todd, C. D. (1979a). Reproductive energetics of two species of dorid nudibranchs with planktotrophic and lecithotrophic larval strategies. Mar. Biol. 53: 57-68

Todd, C. D. (1979b). The population ecology of Onchidoris bilamellata (L.) (Gastropoda: Nudibranchia). J. exp. mar. Biol. Ecol. 41: 213-255

Todd, C. D. (1979c). The annual cycles of two species of Onchidoris (Gastropoda: Opisthobranchia). In: Naylor, E., Hartnoll, R. G. (eds) Cyclic phenomena in marine plants and animals. Pergamon Press, Oxford, pp. 65-72

Turner, R. L., Lawrence, J. M. (1979). Volume and composition of Echinoderm eggs: implications for the use of egg size in life history models. In: Stancyk, S. E. (ed.) Reproductive ecology of marine invertebrates. University of South Carolina Press, Columbia, S. C. (Belle W. Baruch Library in Marine Science, No. 9: 25-40)

Underwood, A. J. (1974). On models for reproductive strategy in marine benthic invertebrates. Am. Nat. 108: 874-878

Vance, R. R. (1973a). On reproductive strategies in marine benthic invertebrates. Am. Nat. 107: 339-352

Vance, R. R. (1973b). More on reproductive strategies in marine benthic invertebrates. Am. Nat. 107· 353-361

Vance, R. R. (1974). Reply to Underwood. Am. Nat. 108: $879-880$

Vernberg, F. J., Costlow, J. D. (1966). Studies on physiological variation between tropical and temperate zone fiddler crabs of the genus Uca. IV. Oxygen consumption of larvae and young crabs reared in the laboratory. Physiol. Zool. 39: $36-52$ 